\title{
Introducing the Complexity of Educational Diversification
}

\section{Kantasalmi, Kari}

Palgrave Macmillan

2017

Kantasalmi , K \& Holm , G 2017 , Introducing the Complexity of Educational Diversification . in K Kantasalmi \& G Holm (eds), The State, Schooling, and Identity : Diversifying Education in Europe . Education Dialogues with/in the Global South , Palgrave Macmillan , Singapore , pp. 1-23 . https://doi.org/10.1007/978-981-10-1515-1_1

http://hdl.handle.net/10138/309978

https://doi.org/10.1007/978-981-10-1515-1_1

acceptedVersion

Downloaded from Helda, University of Helsinki institutional repository.

This is an electronic reprint of the original article.

This reprint may differ from the original in pagination and typographic detail.

Please cite the original version. 


\section{INTRODUCING COMPLEXITY OF EDUCATIONAL DIVERSIFICATION}

\section{This is a self-archived version of the final published chapter (pp.1-23)}

\section{Kari Kantasalmi and Gunilla Holm}

The title of this book "The State, Schooling and Identity: Diversifying Education in Europe" cuts into the complexities of current educational endeavors. It does so by concentrating on European experiences in a series of three volumes, titled "Education Dialogues with/in the global south" edited by Carol Reid and Jae Major. Seen from the perspective of the "global south", Europe is part of the global north. More so, in terms of power issues related to school systems, Europe has been the constitutive context for the underlying model of modern schooling, which from the viewpoint of the "global south" is seen through critical perspectives. Of course, the issue at stake is not merely a geographical one. European minorities are also influenced by the southern theorizing (Connell 2007), pointing out instances of social marginalization or inequality related to dominant forms of schooling. Even in the welfare states of the Nordic countries culturally responsive educational diversifications can appear as means for challenging forms of subjugation through school systems. As editors, we have not imposed any particular theoretical frame for the contributors. Instead, we asked for reflections from settings we thought would be of interest to those following the global education discourse with regard to cultural identities and social inequalities.

\section{WHY SCHOOLING AND EDUCATION?}

Currently we live in and observe a globally extant "schooled society" (Baker 2014), meaning that in societal systems of education emphasis has been put on credentialing aspects of the education process as organized through modern school systems. The expansion of school careers and the spectacular worldwide growth in the number of schools, enrollments and obtained degrees can be easily observed. Such development has been founded on European constituents of schooling and its Euro-American elaborations: This organizational form has narrowed down educational 
communication to the mediation of exams, credentials and degrees, and thus, in organizational terms, homogenized the educational process out of its wider cultural meanings, which nevertheless continue to offer social inspiration for diversity within the modern schooling. In short, schooling has been an essential part of the Western path to modernity, but it is still only one aspect of global education, whether viewed through its practices or communications.

Education in the wider cultural sense offers more institutional connections than its modern organized form of schooling, with certain societal advantages that can explain its successful expansion. There is a tension to be observed between these two aspects. The European accounts presented in this book indicate above all a persistent institutional endurance of schooling despite the apparent intensified complexity in pedagogical arrangements of the school systems in responding to the social expectations for education in diverse cultural meanings. The present selection of reflections is due to the editors' twofold focus on educational diversity: First, we have selected contexts where nation states are problematized through educational developments or vice versa; second, we have chosen well known Nordic welfare state contexts which are problematized through their assumed equality and equity with regard to diversifying education. Both lines of concern point to the complexity of identities in Europe as related to developments in education. Identity is, of course, a multilayered issue and this book approaches it by focusing on current national and regional controversies as well as egalitarian issues related to school internal identities with educational significance, such as teachers' professional identities and students' gender and ethnicities.

The title of the book relates schooling to the fundamental structural coupling of education with the political power concentrations in the forms of the modern state and citizenship. In contrast to 
schooling, education in its wider cultural meaning opens a plethora of diversification possibilities beyond obligations and rights related to the citizenry. Consequently, a person's inclusion in schooling is globally seen still less likely than one's exclusion from all forms of education. Clarity in terms of inclusion or exclusion might also require observers of education to reconsider the epistemic value gained by the common distinction between formal- and informal education. It is hardly possible to observe educational communication or practice entirely free of socially meaningful forms. It is, however, possible to yield better understanding of the effective forms in modern schooling. Steps towards better understanding would allow acknowledging that in its wider meanings education remains open to diversifications related to cultural construction of identities; commonly referring to ethnicity and language, both often associated with the nation. Currently, identities are, however, constructed on many bases, even on choices of life styles with rather limited societal stability. The more fluid we view modernity, the more sensitively we need to observe the instances where communication assumes pedagogically responsible social forms instead of advertising ideological propaganda or some other social source of meaningfulness. Schooling is not a guarantee for neutrality, although in its state controlled form it is expected to manifest public accountability, while education in wider cultural terms can insist on more particular responsibilities.

This book, however, does not consider entanglements of education with consumer identities in the "liquid modern setting" (Bauman 2009), but instead, observes more deeply institutionalized societal interfaces that persistently inspire European educational diversity within the limits of the flexibility of modern schooling. Thus, modern schooling is assumed to be a societally stabile institution which can embrace education in culturally diverse forms. This is also to question the limits of schooling by raising issues of equity from the viewpoint of the cultural responsiveness of education.

Furthermore, the contributions in this book question the capability of school systems to recognize the ways they maintain social inequalities. With the increasing reflexivity of modernity (Giddens 
1990) we are moving towards something like "reflexive citizenry" (Giddens 1994). As far as this is the case, we should inquire about the leeway for more complex identity claims within the structural coupling produced between citizenry and schooling. Recognition of multiple cultural sources of educational diversification is of importance from the egalitarian viewpoint manifested in European conceptions of democracy.

Before offering the overview of the chapters, we first outline the historical constituents for modern schooling to show why it would be important for observers of the world's educational endeavor to resist equating schooling with education. We will then proceed to introduce some general conceptual avenues to foster reflexive gains in grasping the increasing concerns for diversifying education in its connections to credentialing schooling, which is characterized by homogenizing and standardizing procedures. This offers a common ground for the various disciplinary approaches and theories used in the chapters of this book. After introducing the historical constituents of the problems concerned, we explicate the wider topics that appear as sources for these chapters dealing with educational diversity: cultural belonging in terms of nations, regions or ethnicity and egalitarian concerns for social justice. Both topics were present in the constitutive phase of modern schooling and they still are.

Sociological discourse on modernity has, however, turned more reflexive along with experiences gained in discussing globalization. Above all, the Eurocentrism hosted in earlier modernization views has been relinquished, while pointing beyond European modernity, to other "actually existing historical trajectories" or "routes to modernity" and trough them (Therborn 1995, 5-7). ${ }^{\mathrm{i}}$ In his $20^{\text {th }}$ century comparison of the value patterns of European modernity, after the Second World War,

Göran Therborn (1995) could still summarize on the basis of three contentious long-term dilemmas, 
those being secularization and Christianity, nation state and citizenry, individualism and classes. All these are in some meaning present in this book's viewing of the educational diversification demands in Europe. The contributors, however, chose not to discuss the particular challenges posed by religious communities to current secular states in Europe. Demands for multi/inter-cultural education are currently widely discussed elsewhere as educators are trying to work with the intensified complexity of classrooms caused by recent migratory processes. Some might have thought, for a while at least, that nationalism and social ascension had already found rather stable educational resolutions in state coordinated modern schooling. Some might have even assumed that if there is something like a "European identity"-_eeper than the political narrative to foster legitimacy for the European Union governance (Immerfall/Boehnke/Baier 2010)—it would be found in the northwestern heartlands of European modernity. Yet, some chapters in this book deal with resurgent ideology of "nationalism" in Western Europe, which Therborn $(1995,282)$ viewed as having developed to be the "least nationalist part of the world".

\section{HISTORICAL CONSTITUENTS OF MODERN SCHOOLING}

The constitutive ideas for modern schooling stemmed from a more or less clearly demarcated geopolitical area of early modern $\left(16^{\text {th }}\right.$ to $18^{\text {th }}$ centuries $)$ Europe. After the final collapse of the Byzantine Empire (1453) and along with the victorious "Reconquista" against the Muslim occupation in the Iberian Peninsula, followed by Columbus's sailing to the Caribbean in (1492), the inner connectedness of Europe increased in ways not seen before, and European life faced a profound transformation (Tilly 1993, 21-51). This meant, among other things, the emergence of two organizational dimensions to be observed in modernity (Giddens 1990), namely systematic capitalist production and the nation-state. In view of globalization, the institutional clusters in these 
latter dimensions are of European origin (Giddens 1990, 174), and in this originality their developments also conditioned the emergence of state coordinated public schooling in Europe. To understand better the powerful social force of modern schooling, we need to look back to its societal constituents in Europe and, above all, rethink the ways in which we observe and describe current tensions between schooling and educational diversification. Such a more reflexive view requires unfolding the connections of modern schooling in its societal environment and reconsideration of the conceptualities that are drawn upon in a variety of disciplinary views and substantive theories used in describing them. To appreciate the multidisciplinary approach of this book in exploring the relationship between education and nationalism, we need to reflect more deeply on the distinction between schooling and education in the book's title. This will lead us to ask for a sufficiently abstract notion of society, which could serve for grasping the societal environment of schooling and education as well as the attempts of school research in education science to come in terms with a maze of differentiation terminology in current descriptions of educational diversification.

A universal notion of education was present at the dawn of humanity. Schools were known to exist before medieval times and mostly outside Europe. For European constituents of schooling, there is, however, an inspiring etymology for 'school' from the Greek distinction between 'ascholia' and 'schole' via the Latin word 'schola' to denote the organization type of today. At least, for Marcus Tullius, alias, Cicero (106-43 B.C.) the 'schola' meant, among other things, the school (Mikkola 1958). In medieval Europe this word and its derivatives, however, came to entertain meanings quite opposite to its Greek origins, connoting the creative freedom of 'schole' (Hansen 2010). The meanings later became even more distant from the idea of contemplative peacefulness, long conserved, in distinguishing 'vita activa' and 'vita contemplativa' (Arendt 1998). Immanuel Kant in his (1803) pedagogical reflections might have had the remembrance of the Greek origins of the 
word in mind when he acknowledged the necessarily compulsive culture (zwangmässige Kultur) of the school, but did not want it to mean slavish education. As we know, state coordinated compulsory public schooling had become first established in 1770s, in the absolutist state of Prussia. While moving towards the more autonomous discipline of pedagogy, Kant's successor to the Chair of Philosophy at Königsberg, Johann Friedrich Herbart (1776-1841), introduced an elaborated hybrid notion of "educative teaching" (erziehender Unterricht). Niklas Luhmann observed this latter semantic move as conflating the old distinction between (educatio) and (institutio), thus corresponding, at the level of pedagogical semantics with the ongoing functional out differentiation (Ausdifferenzierung), not only, the school like teaching, but also, education as societal system (Luhmann 2002, 102 and 116; Luhmann and Schorr 2000). Herbart's pedagogy envisioned the professional identity of school teachers, but he still wrote, somewhat ambiguously, to the twofold audience of home tutors and public school teachers. The latter were increasingly expected to assume the educative tasks previously attached to the intimacy of the family or to the parochial environment Christianizing local communities. Such societal differentiation was an outcome of complex processes which took place in $18^{\text {th }}$ and $19^{\text {th }}$ century Europe, and in complex entanglement with preceding developments in early modern politics, religion and economics (Vanderstraeten 2004 and 2006). Foucault (2000 would add that the primacy of family as a source of education became challenged not only by the growing interest in pedagogical knowledge but also in medical knowledge. Thus, parents in $18^{\text {th }}$ century France and Germany demanded more attention for infant health care while also expected to hand over their child's later education to normalizing institutions.

To understand the firm structural coupling between state and schooling we refer to Giddens's $(1990,59)$ view of the four interconnected dimensions of modernity. ${ }^{\mathrm{ii}} \mathrm{He}$ criticized much of sociology for assuming a mono-dimensional emphasis, and consequently, claims for the centrality 
of one or another structural nexus in modernity. Historically seen, Europe produced a structural cluster which connected often violently constructed political orders of states with culturally constructed social orders of nations, thus providing a model of effective "bordered powercontainer" (Giddens 1985, 120). These power containers proved to have considerable potential for worldwide expansion (Giddens 1990, 71), most likely because of the possibilities they offered for legitimating the external use of military force and internal surveillance, meaning control of information and social supervision of the ruled (Giddens 1985; Giddens 1990, 59 \& 71). However, sociologically informed reflexive historians, such as Charles Tilly (1993 and 1994), would view European state formation more cautiously and in less generalizing terms than the inspiring shorthand of the sociological discourse of modernity. Tilly $(1993,35)$ himself had been in pains to find a proper name for European state formations before 1800, but decided to call "consolidated state" the type that started to prevail from the $18^{\text {th }}$ century onward, and in its appearance, made almost all preceding states of the world look "puny in comparison".

The consolidated states of Europe formed the context for emerging public schooling, but these state formations were actually ruling heterogeneous territories and aimed to impose unitary and unifying measures in many societal branches that concerned the lives of the ruled. Thus, we might say that schooling became an important institution for further consolidation of states. Tilly, however, abandoned his previous characterization of European states as national states for the simple reason that he though it as misleading as the nation-state, both corresponding poorly to the reality; there were not examples of states with homogenous citizenry drawn from a single homogenous nation. It was rather that European state formation from the $18^{\text {th }}$ century onward brought about the nation state as ideology (Tilly 1993, 35; 1994, 5). This ideology was geared towards a variety of practices relevant for cultural identities, but relying, above all, on performance of schooling as an effective means of setting limits to imagining national cultural orders (Anderson 1991), only to find out that 
education finds ways to feed imagination to contest established national limits. This is still the case as we can see in this book. In light of Chapters 2-6 in this book, we can see how tension between state schooling and culturally responsive education currently is entangled with state formation in Europe. Such processes are not indifferent to the emergence of supranational polities such as the European Union (e.g. Kantasalmi 1995).

Seen in very broad terms, the European foundations for the close connection of state and education as it became modelled in public schooling were, of course, a common heritage of literate developments of human civilization, but particular conditions of Western Europe favored the "lexicographic revolution in Europe" (Anderson 1991, 84), and of creating a particular way to modernity. In this respect, Luhmann (2012, 174-177) stressed the distinguished European way; in market driven and thus decentralized dissemination of information that followed the invention of the printing press, and its connection to the spread of vernacular languages. From the $16^{\text {th }}$ century onwards religious and political market control by means of framing censorship policies were not successful in Europe. The spread of vernacular languages along with the expanding market of the print challenged the position of Latin in the transmission of knowledge and fostered political nationalization. Developments leading to the emergence of public schooling were related to these constitutive processes in nation making and state formation. There were in Europe regionally differing paths in the latter process which led a variety of segmented units to form consolidated states (see; Tilly 1993). In this respect, one significant unit of great importance to the parallel development of scholarly culture was the city (Tilly 1994). However, to understand the process that finally in the $19^{\text {th }}$ century turned states into organizations with multiple purposes, including the coordination and financing of public education, we clearly need to acknowledge the role of the university as an important element in what Tilly (1994) observed as the long "entanglement of European cities and states" from medieval times to the end of the $18^{\text {th }}$ century. 
In European cities there were schools around Cathedrals, but when universities started to be established at the end of the $12^{\text {th }}$ century, they gradually succeeded in developing a rather privileged societal position as guild corporations in a space between the control of the Pope and the Emperor.iii Their corporate jurisdiction was created in order to adjust to the orders of medieval cities and to achieve certain autonomy in theological matters (e.g. Durkheim 1977; Stichweh 1991 and Wei 2012). Later, in the early modern period, a considerable increase in the number of universities in Europe was experienced along with the rise of the "confessional states" (Brockliss 2000). This expansion contributed to the forming of the university as the first form of publicly organized education (Stichweh 1991) and later offered structural support for the differentiation of public education in $18^{\text {th }}$ century Europe (Vanderstraeten 2006). The entanglement of the confessional variety with the rise of public education was of paramount importance for the construction of cultural identities in Europe as seen in the accounts of this book. This was so, above all, in the Nordic countries, where the reformation was not a protest from below but a process fostered by the state, and therefore, no rivalry nor contractual relations between the state and the church existed (Stenius 1997). In consequence, a rather homogenizing Lutheran view prevailed also in forms of popular education developed along the parallel avenue for scholarly education. John Boli (1989) has described the making of the Swedish "mass schooling" as primarily an ideological project from the $17^{\text {th }}$ century onwards. Swedish developments concerned also Finland as part of the kingdom, and thereafter as well when Finland was lost to Imperial Russia, and thus gained the status of an autonomous Grand Duchy of Finland (1809-1917), with its own Estate Diet which was replaced by parliamentary reform of 1907 . The homogenizing Lutheran tradition prevailed in educational evolution and connected to the Finnish nationalism since the second half of the $19^{\text {th }}$ century Finland, and reached beyond the Civil War of 1918 (Kantasalmi and Hake 1997; Kantasalmi 2010). Yet in Northern Scandinavia and Finland the state has never entirely drawn its citizenry from one 
homogeneous nation; as described in chapter 6 of this book, there was always a significant presence of Saami people crossing the borders of what are the independent states of Sweden, Norway (1905) and Finland (1917).

Another important diversification in forms of higher learning related to fostering the practical applications of knowledge in skills and craft technologies needed in expanding long distance trade and in the forming of sea born empires. Thus, for instance, Gresham College, teaching both in Latin and English, was established in London; according to its statutes of 1579, not as a third university beside the universities in Oxford and Cambridge, but for the benefit of the inhabitants of London, which then was a step for founding the Royal Society (Kelly 1970, 26-27; Bernal 1981, 418-20). Sir Thomas Gresham (1519-79) himself has been viewed as "personifying the union between merchant capital and the new science" (Bernal 1981, 419). Early modern European universities developed as an important source for control of the knowledge applied through professional identities, to the extent that in 1605 Francis Bacon assessed as strange that "they are all [great foundations of colleges in Europe] dedicated to professions, and none left free to arts and sciences at large" (Bacon 1952, 30). However, from the $19^{\text {th }}$ century onwards universities were increasingly viewed, not only, through the form of school of traditional professions, but also, from the viewpoint of increasing differentiation of science.

Historical view point justifies resisting the conflation of the notions of schooling and education. In addition, by keeping the distinction epistemically active, there is a possibility for better grasping the political entanglements between modern schooling and the regional or local variation of educational diversity embraced in it. This appears as necessary even for European modernity when it returns to itself, not directly, but enriched with global viewpoints that question Eurocentric universalism and 
aspire for "universal universalism" (Wallerstein 2006). A truly global analysis of education would observe education organized in the form of a school without reproducing the presumptions related to schooling as a necessarily positive social force called progress; a notion that the world could live without before the French revolution. As global connections were intensified, the expansion and extension of modern schooling was, however, coined with progress as depicted after the North American "Civil War"iv in John Gast's 1872 painting "The American Progress"; where such semantic figure in white gown carries a school book under her arm and telegraph wire in her hand, while land is taken over to be cultivated, and natives - uncultivated Indians as they were seen were fleeing seemingly horrified. Later, the early $20^{\text {th }}$ century sociological understanding of modernization smuggled in the viewpoint of Euro-American methodological nationalism to strengthen the image of progressive social development related to expansion of schooling. The powerful image in Gast's painting, described above, could very well be the emblem of EuroAmerican globalization of schooling. The story began in Europe, and sociologists of "mass schooling" would contribute to its conflating with education by stating, that education has "....been reduced largely to formal schooling, despite the lip service given to such notions as 'all life is education' “(Boli and Ramirez 1986, 67).

As far as the world today is a "schooled society" (Baker 2014) and the modern state the central element of the global political structure, we can be sure that citizens of nation states are more or less habituated to observe and discuss education as experienced in massive coursing of several years in school systems, monitored by professionals in teaching and as statistics produced in authorization of these same states. Yet, the state is not to be equated with society, and interstate relations are only a part of what we currently conceive through theories of "world society" (see; Holzer 2015). From the viewpoint of diversity in global system of education, we question the limits of schooling as an "abstract system" which deploys "symbolic tokens" (Giddens 1990), such as certifications and degrees, to the end of hollowing out the situationally embedded complexity of educational 
interaction in order to carry out credentialing procedures, which allow more or less trustworthy guarantees for career decisions to be taken worldwide. We suggest looking critically at the big picture of the world expansion of schooling, which in the last half of the century or so has brought about important transformations and an increasing number of evaluations of school performance, such as PISA. The evaluations are not only to legitimate further credential raise and managerialism through schooling, a powerful modern institution of governance as it is, but also, to evoke second order views and switches of perspectives on schooling. Evaluation emphasis on learning achievements instead of statistics of degree expansion (e.g. Pritchett 2013) starts to question the logic in schooling. Another challenging perspective is arising from the theorizing of the knowledge society. Such visioning leads to policy driven operationalization (Rohrbach 2007; Kantasalmi 2015), but, so far, we know little about how the knowledge society relates to the schooled society (Baker 2014). In this book, Chapter 4 points to the shortcomings of our understanding of knowledge society and offers detailed contemporary analysis of the development in distribution of school credentials in the context of complex regional issues of Belgium. Further elaborations of the issue might lead to looking beyond credentialing schooling to consider the wider cultural meanings of knowledge mediated education and the different ways of knowing. As Chapter 6 shows, the latter epistemic concerns are increasingly raised also from the position of indigenous peoples.

\section{THE COMPLEXITY OF NATIONAL EDUCATION IN SCHOOL SYSTEMS OF EUROPE}

The issues of national education were raised in $18^{\text {th }}$ century Europe. In some parts of Europe these claims were directed also against the educationally active Jesuits, who were not seen as protagonists of national cultural orders (Vanderstraeten 2006). Inquiry into educational diversification is often connected with political struggles or conflicts tied to nations as "particular cultural artefacts" that 
once created (late $18^{\text {th }}$ century) "became "modular"” and thus capable of serving as ideologies with "profound emotional legitimacy" (Anderson 1991, 4) in a variety of contexts. Although the constitutive context for public schooling was driven by the ideology of the nation state, it was not nationalist in the meaning of the ideological tenor of the $19^{\text {th }}$ century or in the meaning of nationalist overtones reached in the educational content of the $20^{\text {th }}$ century Europe. The consequences of the latter are also experienced in this book, especially in Chapter 3, where the memory of "national catholic" education in Franco's Spain is still present. At the other end of the European nation state ideology, there was a negation of the politicized nation in the form of manifest internationalism. Consequently, Chapter 5 reflects on the possibilities to entertain nationalism in "citizenship education" in post-Soviet Ukraine.

Chapters 2, 4 and 6 also discuss the current national complexities in state school systems which were increasingly brought forth from the $19^{\text {th }}$ century onwards. These school systems provided the basis not only for territorially demarcated normalizing effects on $19^{\text {th }}$ century citizenry, but also for further development of the school systems' internal organizational morphology and homogenizing procedures. The latter development urged comparing different state educational systems and thus enhanced the modelling of modern schooling. There were, however, different historical paths into what Margaret Archer described as the endogenous emergence of the "state educational systems", which she $(1979,54)$ defined as a "nationwide and differentiated collection of institutions devoted to formal education, whose overall control and supervision is at least partly governmental, and whose component parts and processes are related to one another." Knowing more about the variety of emergent paths could offer insights also into the current similarities and differences in educational arrangements of European school systems (see e.g. Müller and Kogan 2010). 
By means of distinguishing state and society Archer (1979) reflected on the structural changes common to all "state educational systems"; (unification and systematization) as a consequence of education being related to the state, while (differentiation and specialization) would result from relations between education and society. The social origins of each system matter, according to Archer, with regard to whether it has had a restrictive or substitutive struggle over educational control preceding the emergence of state educational systems, which then became multiply integrated to various societal institutions, but in combinations of structural change. Restrictive strategy was seen by Archer as likely to lead to strong unification and systematization as well as to weak differentiation and specialization, while a substitute strategy was seen as likely to produce converse structural changes with regard to these two sets of patterns. Archer (1979) assumed a certain path dependency for subsequent development of these different outcomes. The important point for further consideration, however, is that such a differentiated system of state coordinated mass schooling assumes its autonomous logic in its further global development. ${ }^{\mathrm{v}}$ The distinction between state and society was of importance for Archer's comparative account, but in historical descriptions she, nevertheless, allowed the nation state to take the place of society. On these bases she even treated $19^{\text {th }}$ century autonomous Finland as part of the Russian Empire, which it was, but not in its scholarly heritage which came from Swedish settlers in Finland, and is still present in the educational developments of Finland, and thus in the background of the discussions in chapters 6, 7 and 11 of this book.

As the model of the nation-state has expanded globally after the Second World War, sociology has often equated the concept of the society with it, and empirically operationalized society as a collection of the independent states of the world. vi To better understand diversifying education in contemporary Europe it would be necessary to construct an epistemic distance to latter cognitive limitation by means of deploying sufficiently abstract theory of society, which allows recognizing 
societal connections of education beyond state coordinated schooling. In order to grasp descriptions related to a variety of educational diversification attempts, we appear to need a sociologically and pedagogically significant distinction between education and schooling as well as a theory of society that would allow for critical distance to be taken to methodological nationalism typical of school research and educational sciences connected to nation state-centered sociology. As the school organization has achieved an important, if not leading, role in the evolution of the societal system of education (Luhmann 2002), also research in educational sciences tends to operate empirically on the offerings of the state's school statistics and occasionally on national reform-based motives. The methodological nationalism can take many forms in social research (see, e.g. Wimmer and Glick Schiller 2002; Burton 1997). Thus sociology has become a victim of its comparative methodology (Luhmann 2012, 92) and school research even more so. In school research it is common to refer to the national systems of education, which are monitored as standardized according to their rather isomorphic organizational form (primary, secondary, tertiary) in levels. Such reductions of educational complexity, in the form of standardizing national data classification, is based on presumed statistical comparability (Raivola 1985) while it ignores local variation which, however, remains to be observed comparatively, meaning indications of similarity or difference with significance according to the "cultural belonging" (Therborn 1991) of the observer. Thus, the modern system of schooling as modelled on a Euro-American basis has been expanded worldwide, not only due to the long-term imposition of the Western school organization, but also due to its standardizing global monitoring and consequent fostering of isomorphism implying homogenizing reductions of educational diversity and eventual losses in local cultural pertinence.

The triumph of mass schooling since the Second World War can be depicted in the light of the global school enrollment data, as demonstrated since the 1970s by the so-called "world cultural approach" of researchers, associated with John W. Meyer and his colleagues at Stanford University, 
who later started to identify themselves through neo-institutional organization theories while drawing upon, among other sources, Anthony Giddens's structuration theory and Pierre Bourdieu's theorizing of social fields. Thus, in the rear mirror view Baker (2014) coins the approach, which is also his, as "neo-institutionalism". Roger Dale (2000) labeled the group as "world institutionalists" while pointing to their long-term undertaking as a demonstration of hypothesized "common world educational culture" which propels the global spread of schooling "almost by osmosis". The globally institutionalized nation state organization, however, was seen to be of importance in their view of the spread of the world educational culture (Meyer/Boli/Thomas/Ramirez 1997) and the eventual making of the "schooled society" (Baker 2014). There are, however, alternatives to viewing world society with an emphasis on an interstate political structure (see, Holzer 2015) where primacy would be given to the theory of functional differentiation of global systems of communication, and consequently to theorizing society as a special social system which encloses all other social systems, and thus, logically, leads to viewing a one world society (see; Luhmann 1997; 2012 and 2103). For the purpose of clarifying the many uses of diversification terminology in current school research, Chapter 7 explores the possibilities in Luhmann's societal theory. A system's theoretical reading of Luhmann's theory of society, however, might offer more possibilities for further elaborations on inner differentiations of the function system of education as observed through national schools systems.

\section{CHALLENGES OF EDUCATIONAL DIVERSITY IN THE WELFARE STATE}

The image of the ideal citizenry is intrinsic for the nation state ideology, and thus offers legitimation for viewing education as the task of the state. Membership of the nation state, marked in citizenship, implies rights which have been viewed as evolving. For instance, as described in the 
British context Marshal (1950) viewed rights as expanding from civil rights via political rights to finally social rights. Richard Münch $(2001,94)$ even viewed in such development a possible "embodiment of the modern ethics". In Marshal's classical account, citizenship meant a drive towards equality and the social class meant inequality, while education played a two-way role between these two organization principles. On the one hand, class was anchored in education and, on the other hand, education offered ways of lifting the anchor and striving for social mobility towards equalizing the citizenry, especially when social or "welfare rights" started to expand during the $20^{\text {th }}$ century, and gradually turned the whole issue of citizenship rights far too complex to be observed through the presumed centrality of class (see Held 1989). The need for a more differentiated view of reflexive citizenship and welfare rights has become acknowledged (e.g. Giddens 1994, 132).

While recognizing the achievements in the reduction of economic inequality in the Nordic welfare states, Giddens's focus was turned to redistribution in terms of sharing risk, which led him to distinguish between external risks and manufactured risks. In his view, the former kinds of risks have prevailed in welfare states due to their origins being incalculable social security provisions. The manufactured risks, instead, due to their reflexive engagement to amaze of life political issues avoid the simple bookkeeper logic and call for generative political programs designed in cooperation with expert systems (Giddens 1994, 152-157; see also Luhmann 1993 for elaborate analysis on the concept of risk). However, we still tend to consider the welfare state very much from the view of its origins in social security. Above all, the electoral behavior in politics tends to economize the welfare state in reference to the scarcity of public funding. Thus, when the state assumes more extensive tasks than its mere compensatory social security role, it faces a dilemma which Luhmann $(2000,215)$ viewed as intensifying considerations between variation and redundancy. That is to say, some tend to increase the tasks of the state, while others would refer to 
the redundancy of these tasks. Both viewpoints, if only in electoral terms, claim as accountable for the economic policy which aims to secure employment and public revenues via taxation (see;

Giddens 1994, 153). Such forms of political communication about public tasks within the frame of national economies is still very much the essence of what we have been used to calling the welfare state, especially, since the second half of the 20th century. In reconstruction contexts following the Second World War, the economic policy was more nation state determined than it is at the beginning of the 21 st century, which has brought about increasing competitive elements and pressure for deconstruction of the welfare state programs, but not much novelty in their rethinking. In a way, the welfare state is still a political form for compensating or capturing inclusion problems, which are typically left to organizational decision making among the citizenry with social rights framed within national laws and economies. As a consequence, the welfare state programs have difficulties with the world societal development (Stichweh 2005), such as, intensified migratory processes. That is to say, passports matter and stateless individuals, in particular, are in danger of accumulated exclusions of different function systems.

We believe, that the welfare state is being rethought in the $21^{\text {st }}$ century, not only because this political form has been exposed to the so-called neoliberal attack in the past few decades, but also based on the structural issues mentioned above. We therefore asked for recent reflections from two Nordic welfares states. Sweden has often been mentioned as one of the most developed in this sense, but appears to be recently contested with regard to its former guiding principles of its school system (Francia 2014). Finland's PISA fame in school attainment has been firmly connected to the egalitarian welfare state ideology in its long-term development (Antikainen and Pitkänen 2014), which can be questioned, as in Chapter 8, through theorizing the "cultural capital" in terms of discussing Pierre Bourdieu's heritage. In addition, the increasing cultural diversity and teachers' capability of working with it in egalitarian ways, as manifested in welfare state ideology, is 
examined critically (Chapter 11) at the school level in Finland. It appears that modern schooling can bring about strong professional identity among teachers, which in practice, however, assumes homogeneity among students and reproduces the image of normality as ethnically Finnish.

In short, there has been a strong egalitarian tone in Nordic welfare state thinking about educational rights. The basic education reforms started from Sweden, and were finalized subsequently in a unified nine year comprehensive school systems in Sweden 1962, Norway 1969, Finland 1970, and Denmark 1975. In these schools free of tuition and other costs, the key idea was to keep the whole cohort together without significant differentiations or segregation, and special education arrangements were intended to be integrated. Thus a switch of viewpoint from equality to equity has been seen behind these reforms (Langfeldt 2011). Gender equity has been one of the major concerns in the past few decades, particularly in Swedish schooling. According to the recent gender inequality index of the UNDP, Sweden stands out as the most egalitarian context in the world (Therborn 2013, 106). Therefore, empirical considerations of gender equity in Swedish secondary schools (Chapter 9) can inspire further reflections on persistent operation modes of modern schooling. Furthermore, the ethnic diversification of the student populations in national school systems seem to be raising questions concerning inequalities of a North-South character also in the Nordic countries. Such experiences as in Chapters 6 and 11 can lead to rethinking educational responsiveness in the welfare state in more reflexive terms. Intensified immigration and transnationalism can cause challenges to the welfare state-based thinking of the national school system (Antikainen/Pitkänen 2014), while new ways of looking at this political form bound to the membership of the nation states can be wished for. Citizenship rights are still an important issue with regard to ethnicity and the domain of capitalist production. We therefore believe that it is also important to foster theoretical reflections on the current state of affairs with regard to schooling and education in the Nordic welfare states. Thus, Chapter 10 looks for theoretical perspectives of 
recognition from the class-based conceptuality, while Chapter 7 seeks inspiration from the recent societal theory of Niklas Luhmann in order to make sense of the terminology used in educational science to observe recent diversifications in education. This is why in this introductory chapter we have offered some theoretical references to schooling and education viewed from the perspective of theorizing social systems based on communication rather than action.

\section{OVERVIEW OF THE BOOK}

The chapters are organized according to two major topics. tw. The first part of the book consists of five chapters and is focused on nationalism in education in four different states. In this part, Europe's internal North-South issues are examined through struggles for independence in connection to educational issues, but language issues are also brought up as a key issue in nation building.

In Chapter Two Education and Nationalism in Scotland: Nationalism as a Governing Resource, Jenny Ozga explores how nationalism and the creation of a national identity is played out in the educational domain of Scotland and its quest for independence. She examines how the Scottish National Party has used educational policies, such as a comprehensive school and higher education without tuition fees, to distinguish Scotland from the United Kingdom and develop as well as strengthen national identity. The Scottish government is strongly relying on education for building the nation and obtaining independence.

In Chapter Three Language, National Identity and School: The Role of the Catalan Language Immersion Program in Catalonian Nationalism, Montserrat Clua i Fainé connects in many ways to the same issue of the importance of education in a nation's fight for independence. In the case of Catalonia, it is the Catalan language and related language policies that form the backbone of the political struggle. Clua i Fainé focuses in particular on the role of public schools in Catalan 
language immersion and how it is part of building Catalan nationalism. Schools are a battlefield between the Catalan and Spanish language but also between Catalan and Spanish nationalisms.

In Chapter Four Geographical Divergences of Educational Credentials in the Modern Nation-State: A Case-Study of Belgium, 1961-2011, Raf Vanderstraeten and Frederik Van der Gucht discuss the structural description of the society in terms of knowledge society as it is currently often seen, through investments in human capital. The latter is customarily conceived in the development and distribution of educational credentials of populations in certain territorial demarcations and time spans. They offer a brief historical background for regionalized educational development and then focus on geographical divergences with attention to top and bottom ends in the regional distribution of human capital. As European regions currently search for knowledge intensive openings in the economy, their empirical findings suggest that, in the case of Belgium, the success of a region relates to the abundance of a highly schooled labor force as well as to the regions ability to avoid relatively large shares of less schooled labor.

In Chapter Five Nationalism as a Positive Value?, Tetyana Koshmanova and Tetyana Ravchyna discuss a project where nationalism is used as a resource for national identity formation in a teacher education program in the Ukrainian crisis situation. They use a diverse group of pre-service teachers' beliefs and values as the basis for exploring Ukrainian nationalism using a democratic teaching approach. The goal of the project is to explore whether in an extreme social crisis situation nationalism and national identity development can be used to further peace.

Chapter Six Saami Educational and Knowledge Claims in School Systems of the Nordic Countries, Irja Seurujärvi-Kari and Kari Kantasalmi connect to the national identity and language issues as well as to equality and equity issues in the Nordic countries. The focus of the chapter is on the Saami as an indigenous people in the transnational region across Finland, Norway and Sweden, and their struggles for linguistic and educational rights. The equity issues within schooling in this 
context also resonate with epistemic concerns of education, inspiring second thoughts on what is meant by knowledge society.

The second part of the book puts the spotlight on the Nordic countries which are generally known for providing high quality and fair education for all. Many of the national curricula in the Nordic countries have equality and equity as founding pillars for their educational systems. The Nordic states have always been diverse with regard to social class, national minorities, religion and gender, but they have over the last few decades become increasingly diverse with regard to ethnicity due to increased migration. The diversification of the student populations in the educational systems is raising questions and leading to inequalities of a North-South character also in Nordic schools with persistent inequalities in relation to, for example, gender, ethnicity, class and cultural capital.

\section{In Chapter Seven Differentiation and Diversification in Compulsory Education: A Conceptual} Analysis, Lauri Ojalehto, Mira Kalalahti, Janne Varjo, and Sonja Kosunen delve into the meanings and challenges of the concepts of differentiation and diversification as they play out in research on comprehensive schooling. What does school differentiation mean from the perspective of, for example, diverse student populations? What are some of tools available for understanding the processes through which differentiation develops in our schools? The authors also connect the two main concepts discussed to related concepts such as stratification.

In Chapter Eight Cultural Capital, Equality and Diversifying Education, Anna-Kaisa Berisha, Risto Rinne, Tero Järvinen and Heikki Kinnari discuss how equality in education has been reconceptualized over time in Finland and how the mechanisms of educational selection have actually maintained inequality at all levels of schooling in a situation of diversifying education. They focus on the importance of institutionalized cultural capital in the social reproduction and social inheritance of education. 
In Chapter Nine Discourses on Gender and Achievement in Lower Secondary Education, Elisabet Öhrn, Lisa Asp-Onsjö and Ann-Sofie Holm examine gender differences in school achievement in Sweden and the communication processes contributing to the differences. The research is based on a study of nine schools in both rural and urban contexts. The study confirms previous studies showing that valued masculinities are related to non-school work, but this study also shows that high achieving boys can obtain a high status among peers and teachers. For both boys and girls, being high achieving due to being talented is more appreciated and recognized than being high achieving due to hard work.

In Chapter Ten Justice in Education in the Nordic countries: Perspectives, Challenges and Possibilities, Dennis Beach discusses how the core values of equal opportunities and social justice form the foundation of the educational systems in the Nordic countries. He questions whether school systems in the Nordic countries are as successful in working for a socially just education as they are claimed to be. He does this both at a theoretical level using Nancy Fraser's concept of recognition as well as some neo-Marxian concepts with regard to educational practices and outcomes.

In Chapter Eleven Not All Students Are Equally Equal: Normality as Finnishness, Ina Juva and Gunilla Holm go in depth with how equality is played out in daily life in two lower secondary schools in Finland. They explore the processes of exclusion and marginalization migrant students encounter in school, despite the claims of school being equal for all. Many teachers have different expectations of migrant students and make distinctions between normal Finnish students and 'less normal' or too different migrant students because the migrant students are not considered Finnish enough.

References 
Alatas, S. F. 2006. From Jāmi' ah to University: Multiculturalism and Christian-Muslim Dialogue. Current Sociology January 2006 54: 112-132

Anderson, B. 1991. Imagined Communities: Reflections on the Origin and Spread of Nationalism. London: Verso.

Antikainen, A. and Pitkänen, A. 2014. A history of educational reforms in Finland. In; Verdugo,

R.D. (Ed.) Educational Reform in Europe: History, Culture and Ideology. Charlotte, NC.

Information Age Publishing. pp. 1-24.

Archer, M.S. 1979. Social Origins of Educational Systems. London: Sage Publications.

Arendt, H. 1998. The Human Condition. London: University of Chicago Press.

Bacon, F. 1952. Advancement of Learning. Chicago: Encyclopedia Britannica and University of Chicago.

Baker, D-P. 2014. The Schooled Society: The educational transformation of global culture.

Stanford, California: Stanford University Press.

Bauman, Z. 2009. Education in the Liquid-Modern Setting. Power and Education, Vol. (1), 2, pp.157-166

Bernal. J.D. 1981. Science in History. Vol 2. Cambridge, Mass. M.I.T Press.

Boli, J. (1989). New citizens for a new society: the institutional origins of mass schooling in Sweden. Oxfordf: Bergamon Press.

Boli, J. \& Ramirez, F. (1986). World Culture and the Institutional Development of Mass Education. In: Richardson, J. G. (Ed.) Handbook of Theory and Research for the Sociology of Education. New York: Greenwood Press. 
Brockliss, L. 2000. Gown and Town: The University and the City in Europ1 1200-2000. Minerva 38: $147-170$

Dale, R. 2000. Globalization and Education: Demonstrating a 'Common World Educational Culture” or locating a 'Globally Structured Educational Agenda'? Educational Theory. Vol 50. 4; pp. $427-448$

Durkheim, E. 1977. The Evolution of Educational Thought: Lectures on the formation and development of secondary education in France. London: Routledge \& Kegan Paul.

Francia, G. 2014.Education Reform in Swede: From “One School for All Children” to "One School for Each Child”. In; Verdugo, R.D. (Ed.) Educational Reform in Europe: History, Culture and Ideology. Charlotte, NC. Information Age Publishing. pp. 25-40.

Foucault. M. 2000. Los Anormales. Buenos Aires. Fondo de Cultura Económica de Argentina.

Garsoian. N.G. 1985. Chapters 36, 37, 38, 52. In Garraty, J.A. \& Gay. P. (eds.) The University history of the World. New York. Harper \& Row.

Giddens, A. 1985. The Nation-State and Violence: Vol. 2. A Contemporary Critique of Historical Materialism. Cambridge. Polity Press.

Giddens. A. 1990. The Consequences of Modernity. Cambridge: Polity Press.

Giddens, A. 1994. Beyond Left and Right: The future of radical politics. Cambridge: Polity Press.

Green, A. 1990. Education and State Formation: The Rise of Education Systems in England, France and the USA. Houndmills. Macmillan Press.

Hansen, M.H. 2010. Greek, Roman, and Byzantine Studies 50 (2010) 1-27 
Held, D. 1989. Citizenship and autonomy. In; Held, D. and Thompson, J.B. (eds.) Social theory of modern societies: Anthony Giddens and his critics. Cambridge, Cambridge university press. pp. 162-184.

Holzer, B. 2015. 'The Two Faces of World Society: Formal structures and Institutionalized Informality' in B. Holzer, F. Kastner and T. Werron (Eds.) From Globalization to World Society: Neo-Institutional and Systems-Theoretical Perspectives. New York: Routledge. pp. 37-60.

Immerfall, S. Boehnke, K. and Baier, D. 2010. Identity. In: Immerfall, S. and Therborn, G. (Eds.) Handbook of European Societies. New York: Springer, pp. 325-353.

Kantasalmi, K. 2015. University and the contingencies in politics of research, development and innovations: Finnish reform of doctoral schools and doctoral programs. In: Langemeyer, I.; Fischer M. \& Pfadenhauer M. (Eds.), Epistemic and learning cultures: wohin sich Universitäten entwickeln. Weinheim, Bergstr: Beltz Juventa, pp. 115-137.

Kantasalmi, K. 2010. Profession or Professionalism? Theoretical Problems in Describing the Teacher's Occupation and the Changing Nature of University Education. In: Kauko, J. Rinne, R \& Kynkäänniemi H. (Eds.) Restructuring the Truth of Schooling: Essays on Discursive Practices in the Sociology and Politics of Education. Helsinki: Finnish Educational Research Society, pp. 150175.

Kantasalmi, K. \& Hake, B. J. 1997. Popular adult education in Finland 1890-1939: a critical reinterpretation of the 'people's enlightenment project'. History of Education, 26(4), 353-374.

Kantasalmi, K. 1995. Sistemas supra-nacionales, educación de adultos y cambio social: observaciones socio-históricas en el contexto Europeo. Revista de Educacion, (308), 195-213

Kelly, T. 1970. A History of Adult Education in Great Britain. Liverpool: Liverpool University Press.

Langfeldt, G. 2011. The rationality of large scale reforms: 'Scandinavian neo-institutionalism' as an example. In: Gogolin, I; Baumert, J: Scheunpflug (Hrsg.) Transforming Education. Umbau des 
Bildungswesens: Large-scale Reform Projects and their Effects. Zeitschrift für

Erziehungswissenchaft. Sonderheft 13, 2011, pp. 51-66.

Luhmann, N. 1990. Political theory in the Welfare State. Berlin. Walter de Gruyter.

Luhmann, N. 1993. Risk: A Sociological Theory. Berlin. Walter de Gruyter.

Luhmann, N. 1997. Globalization or World Society: How to Conceive of Modern Society? International Review of Sociology. Vol. 7, Nr. 1, pp. 67- 79.

Luhmann, N. 2000. Die Politik der Gesellschaft. Frankfurt am Main: Suhrkamp.

Luhmann, N. 2002. Das Erziehungssystem der Gesellschaft. Frankfurt am Main: Suhrkamp.

Luhmann, N. 2012. Theory of Society. Vol 1. Stanford: Stanford University Press.

Luhmann, N. 2013. Theory of Society. Vol 2. Stanford: Stanford University Press.

Luhmann, N. and Schorr, K-E. 2000. Problems of Reflection in the System of Education. New York: Waxman Münster.

Markopoulos, A. 2008. "Education", in Jeffreys, E.; Haldon, J. F.; Cormack, R., The Oxford handbook of Byzantine studies, Oxford Handbooks in Classics and Ancient History, Oxford: Oxford University Press, pp. 785-795.

Marshall, T.H. 1950. Citizenship and Social Class and other Essays. Cambridge: Cambridge University Press.

Meyer, J., Boli. J., Thomas, G.M and Ramirez, F.O. (1997). World Society and the Nation-State. American Journal of Sociology. Vol. 103, No. 1, pp. 144-181.

Mikkola, E. 1958. "Schole" bei Aristoteles. Helsinki: Arctos, Acta Philologica Fennica. Nova Series Vol. II, 68-87.
Muotoiltu: saksa (Saksa)

Muotoiltu: englanti (Yhdysvallat) 
Müller, W, and Kogan, I. (2010). Education. In: Immerfall, S. and Therborn, G. (Eds.) Handbook of European Societies. New York: Springer, pp. 218-289.

Münch, R. 2001. The Ethics of Modernity. Lanham. Rowman \& Littlefield Publishers.

Pritchett, L. 2013. The Rebirth of Education: Schooling Ain't Learning. Washington, D.C. Center for global development.

Raivola, R. 1985. What is Comparison? Methodological and Philosophical Considerations.

Comparative Education review, Vol. 29, No. 3, pp. 362-374.

Rohrbach, D. 2007. The development of knowledge societies in 19 OECD countries between 1970 and 2002. Social Science Information Vol 46 (4), pp. 655-689.

Stenius, H. 1997. The Good Life is a Life of Conformity: The Impact of Lutheran Tradition on Nordic Political Culture. In: Sørensen, Ø. and Stråth, B. (Eds.) The Cultural Construction of Norden, Oslo, Scandinavian University Press. pp, 161-171.

Stichweh, R. 1991. Der Frühmoderne Staat und die europäische Universität: Zur interaktyion von

Politik und Erziehungssystem in Prozess ihrer Ausdifferenzierung (16.-18. Jahhundert). Frankfurt am Main: Suhrkamp.

Stichweh, R. 2005. Inklusion und Exklusion: Studien zur Gesellschaftstheorie. Bielefeld:

Transcript.

Therborn, G. 1991. Cultural Belonging, Structural Location, and Human Action: Explanation in sociology and in Social Science. Acta Sociologica, 34: 177-191.

Therborn, G. 1995. European Modernity and Beyond: The Trajectory of European Societies 19452000. London: Sage Publications.

Therborn, G. 2013. The Killing Fields of Inequality. Cambridge, Polity Press.

Tilly, C. 1993. European Revolutions 1492-1992. Cambridge, Mass: Blackwell Publishers. 
Tilly, C. 1994. Entanglements of European Cities and States. In; Tilly, C. and Blockmans, W.P (Eds.) Cities and the Rise of States in Europe, A.D. 1000 to 1800. Boulder: Westview Press.

Vanderstraeten. R. 2004. The Social Differentiation of the Educational System. Sociology. Vol 38 (2):255-272

Vanderstraeten, R. 2006. The Historical Triangulation of Education, politics and Economy. Sociology. Vol 40 (1):124-142

Wallerstein, I. 2006. European Universalism: The Rhetoric of Power. New York: The New Press.

Wei, I.P. 2012. Intellectual Culture in Medieval Paris: Theologians and the University, c. 1100-

1300. Cambridge: Cambridge University Press.

'Therborn distinguished four patterns of modernization; 1) European, 2) New World pattern (primarily Americas); 3) Colonial Zone stretching from Northwestern Africa to Papua New Guinea and South Pacific; as well as those parts of the New world were indigenous populations managed to survive 4) Externally induced modernization (Japan and Russia from the 18th century onwards) challenged by new imperial powers of Europe and America.

ii Those being: 1) Surveillance, meaning control of information and social supervision, commonly associated with in global terms nation states, especially when connected to other dimensions, namely 2) military power, meaning control of the means of violence in the context of the industrialization of the war, 3) industrialism, meaning transformation of nature and the development of artificial environments, 4) capitalism, with focus on capital accumulation in the context of competitive markets.

iii European university probably drew also upon preceding learned experiences around the Mediterranean, and in contacts between the surrounding literary civilizations. The medieval university, however, was original in ways it became related to societal development. From the point of view of Christian -Muslim dialogue Islamic influences for European university have been argued by pointing to organizational affinities across the historical forms in educational arrangements (e.g. Alatas 2006). Byzantine history would point to the year 425 when Theodosius II

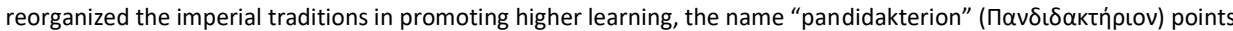
to ample areas of knowledge and teaching in this institution, which developed for centuries as linked with the imperial court and channeled access to offices of importance (Garsoian 1985; Markopoulos 2008). With the decline of

Byzantine Empire the latter institution lost significance. Observing the Eastern frontier of Western Europe we should, however, credit the learned center of Constantinople as it after A.D. 860, with the help of missionary students Cyril and Methodius seeded the Cyrillic alphabet and translation of the liturgy to Slavic peoples.

iv See Benedict Anderson's $(1991,201)$ comment on the nationalist significance of the "pedagogical industry" in the USA, in purporting remembrance of the conflict of 1861-65 as civil war and forgetting it as war between two sovereign nation-states, which they briefly were. Had the war ended in maintaining the independence of Confederacy, schooling would have most likely contributed to the forgetting the conflict as civil war $v$ For a compact overview of Archer's (1979) scheme see Andy Green (1990, 67-75) and the Marxian inspired critique of her short comings in theorizing the state (Green, ibid, 76-110)

vi In July 2015 U.S. State department listed 195 independent states in the world. http://www.state.gov/s/inr/rls/4250.htm

Poistettu: ๆ

Kentän koodi muuttunut 
After the update in 2011 the organization of United Nations had 193 members

http://www.un.org/en/members/growth.shtm

European Union has 28 member states after accession of Croatia in 2013.

http://europa.eu/about-eu/countries/member-countries/
Kentän koodi muuttunut

Kentän koodi muuttunut 